\section{Union of South American Nations (UNASUR)}

History. Established in May 2008 in Brazil, it is anticipated that the Union of South American Nations will eventually supersede Mercosur and the Andean Community, creating an enlarged customs union with a single market, parliament, secretariat and central bank, based on the European Union structure. UNASUR is the successor body to the now defunct South American Community of Nations (CSN/SACN), founded in 2004. However, insufficiently defined goals and ongoing disputes between members of the already-existing blocs may hamper development, as may the growing US military presence in Colombia and future bilateral trade negotiations with the USA.

Members. Argentina, Bolivia, Brazil, Chile, Colombia, Ecuador, Guyana, Paraguay, Peru, Suriname, Uruguay, Venezuela.

\section{Asian Development Bank}

A multilateral development finance institution established in 1966 to promote economic and social progress in the Asian and Pacific region, the Bank's strategic objectives are to foster economic growth, reduce poverty, improve the status of women, support human development (including population planning) and protect the environment.

The bank's capital stock is owned by 67 member countries, 48 regional and 19 non-regional. The bank makes loans and equity investments, and provides technical assistance grants for the preparation and execution of development projects and programmes; promotes investment of public and private capital for development purposes; and assists in co-ordinating development policies and plans in its developing member countries (DMCs).

The bank gives special attention to the needs of smaller or less developed countries, giving priority to projects that contribute to the economic growth of the region and promote regional co-operation. Loans from ordinary capital resources on non-concessional terms account for about $80 \%$ of cumulative lending. Loans from the bank's principal special fund, the Asian Development Fund, are made on highly concessional terms almost exclusively to the poorest borrowing countries.

Regional members. Afghanistan, Armenia, Australia, Azerbaijan, Bangladesh, Bhutan, Brunei, Cambodia, China, Cook Islands, Fiji Islands, Georgia, Hong Kong, India, Indonesia, Japan, Kazakhstan, Kiribati, South Korea, Kyrgyzstan, Laos, Malaysia, Maldives, Marshall Islands, Micronesia, Mongolia, Myanmar, Nauru, Nepal, New Zealand, Pakistan, Palau, Papua New Guinea, Philippines, Samoa, Singapore, Solomon Islands, Sri Lanka, Taiwan, Tajikistan, Thailand, Timor-Leste, Tonga, Turkmenistan, Tuvalu, Uzbekistan, Vanuatu and Vietnam.

Non-regional members. Austria, Belgium, Canada, Denmark, Finland, France, Germany, Ireland, Italy, Luxembourg, Netherlands, Norway, Portugal, Spain, Sweden, Switzerland, Turkey, UK, USA.

Organization. The bank's highest policy-making body is its Board of Governors, which meets annually. Its executive body is the 12member Board of Directors (each with an alternate), eight from the regional members and four non-regional.

The ADB also has resident missions: in Afghanistan, Armenia, Azerbaijan, Bangladesh, Cambodia, China, India, Indonesia, Kazakhstan, Kyrgyzstan, Laos, Mongolia, Nepal, Pakistan, Papua New Guinea, Sri Lanka, Tajikistan, Thailand, Uzbekistan,
Vietnam; a Pacific Liaison and Co-ordination Office in Sydney; and a South Pacific Subregional Office in Suva, Fiji Islands. There are also three representative offices: in Tokyo, Frankfurt and Washington, D.C.

Official language: English.

Headquarters: 6 ADB Avenue, Mandaluyong, Metro Manila, Philippines.

Website: http://www.adb.org

President: Haruhiko Kuroda (Japan).

\section{Asia-Pacific Economic Co-operation (APEC)}

Origin and Aims. APEC was originally established in 1989 to take advantage of the interdependence among Asia-Pacific economies, by facilitating economic growth for all participants and enhancing a sense of community in the region. APEC is now the premier forum for facilitating economic growth, co-operation, trade and investment in the Asia-Pacific region. APEC has a membership of 21 economic jurisdictions, a population of over $2 \cdot 5 \mathrm{bn}$. and a combined GDP of US $\$ 19$ trn. accounting for $47 \%$ of world trade. APEC is working to achieve what are referred to as the 'Bogor Goals' of free and open trade and investment in the Asia-Pacific area.

Members. Australia, Brunei, Canada, Chile, China, Hong Kong, Indonesia, Japan, South Korea, Malaysia, Mexico, New Zealand, Papua New Guinea, Peru, Philippines, Russia, Singapore, Taiwan, Thailand, USA and Vietnam.

Activities. APEC works in three broad areas to meet the Bogor Goals. These three broad work areas, known as APEC's 'Three Pillars', are: Trade and Investment Liberalization-reducing and eliminating tariff and non-tariff barriers to trade and investment, and opening markets; Business Facilitation-reducing the costs of business transactions, improving access to trade information and co-ordinating policy and business strategies to facilitate growth, and free and open trade; Economic and Technical Co-operationassisting member economies build the necessary capacities to take advantage of global trade and the new economy. The 20th APEC Ministerial Meeting, held in Lima, Peru in Nov. 2008, had as its theme 'A New Commitment to Asia-Pacific Development'

Official language: English.

Headquarters: 35 Heng Mui Keng Terrace, Singapore 119616.

Website: http://www.apecsec.org.sg

Executive Director: Muhamad Noor Yacob (Malaysia).

\section{Association of South East Asian Nations (ASEAN)}

History and Membership. ASEAN is a regional intergovernmental organization formed by the governments of Indonesia, Malaysia, the Philippines, Singapore and Thailand through the Bangkok Declaration which was signed by their foreign ministers on 8 Aug. 1967. Brunei joined in 1984, Vietnam in 1995, Laos and Myanmar in 1997 and Cambodia in 1999. Papua New Guinea also has observer status. The ASEAN Charter, signed in Nov. 2007, established the group as a legal entity and created permanent representation for members at its secretariat in Jakarta. 